Image and Man - Correlations, eds. Marcin Godawa, Bojan Žalec, Krakow 2020, pp. 11-20.

DOI: http://dx.doi.org/10.15633/9788374386807.02

Bojan Žalec

University of Ljubljana, Slovenia

\title{
Kierkegaard and Becoming an Image of God
}

The aim of this paper is to present Kierkegaard's view on what it means to become an image of God, or with other words how to become a self (or a selfhood) before God or a single individual. All these four terms have, basically the same meaning in the frame of Kierkegaard's thought, and refer to the main human goal, the telos of our existence. The proper love plays a crucial role in the process of its achieving. Therefore, we explain Kierkegaard's account of correct or true love. We find out that according to Kierkegaard, our love is correct if it helps people to become the image God intended for them. Kierkegaard is a representative of ethics of God's call and self-actualization. For this reason, we base our explanation on Kierkegaard's consideration of ways of human response to God's call, dimensions of human existence, human transformation, and the fundamental role of human openness to God in it.

\section{GOD'S CALL AND HUMAN RESPONSE - THE BASIC MATRIX OF KIERKEGAARD'S THOUGHT}

American Christian theologian Charles K. Bellinger points out that "Kierkegaard understood the world as a sphere of the creative activity of God." (Bellinger 2015 [hereafter TS], loc. 548-51) Kierkegaard took the claim about God's creation of the world and its beings through speech very seriously. As Bellinger expressed this Kierkegaard's view: "Everything that exists does 
so because God is speaking it into existence." (TS, loc. 584-51) Bellinger's main point is that the central moment in Kierkegaard is the relationship between God and man, between God's call to man to grow, to become a self before God - a mature person who is motivated by faith, hope and love - and man's answer to this call. This growth or becoming involves pain. Humans react to this in different ways. Some of them try to avoid this pain and deafen themselves to the call. Kierkegaard calls such an attitude and a corresponding way of life a being to death.

There are three dimensions of human existence: 1. the vertical axis: God and nature; 2 . the horizontal axis: social existence; 3 . the temporal trajectory of individual selfhood. These dimensions offer us a ground to understand Kierkegaard. His view on the defections in the three dimensions is the following (TS, loc. 644-46):

1. the vertical dimension - mutiny against God;

2. selfhood - resistance to the call to growth;

3. the horizontal dimension - the crowd is untruth.

We can notice the interconnectedness - in Kierkegaard's thinking - of love for God, self and neighbour (TS, loc. 644-46ff).

That we are all called by God to become a mature person who loves others is the central topic of Works of Love (TS, loc. 656-59). This work is an extended meditation on the creative speech of God (TS, loc. 656-59), which very concretely comes to us with the words of Jesus that we must love the other as we love ourselves. We can become an individual before God, a Self. This happens when we lift from the horizontal level (society) through development and growth of the individual self to God (the vertical axis). But, Kierkegaard is not a "Gnostic" who wants to leave the world. He returns back to the world where he tries to love his neighbour as himself. The individual who stands before God, the self, is motivated by faith, hope and love (TS, loc. 678-80).

The process of the transformation to self can be described, according to Bellinger, by the Greek word askesis (TS, loc. 680-83). Its original meaning was athletic training or practice, for instance training for the Olympics (TS, loc. 680-83). Yet in the early Christianity, the term was translated into the spiritual context, and referred to exercises of monks and nuns for the purpose of greater openness to God. One of Kierkegaard's works is called Practice in Christianity. Bellinger points out that "the Danish term Indøvelse, translated as practice, or as training in the earlier edition, is the direct equivalent of askesis." (TS, loc. 683-92) He explains further: 
For Kierkegaard, spiritual growth is a Christological event. We become individuals before God by modelling ourselves after Christ, who is the prototype of true selfhood. When this point is not understood, critics interpret Kierkegaard's comments on 'the single individual' out of context and accuse him of 'individualism.' In reality, Kierkegaard's understanding of what it means to be individual before God, truly loving the neighbor, shows that the ultimate antidote for modern individualism is Christian askesis. (TS, loc. 683-92)

The three aspects of reality and the questions connected with them - who is God, who are we, and what should we do - are mutually connected with bonds which cannot be broken. This means that we cannot separate one of them from the other two without starting a war against reality. If we try to comprehend ourselves as human beings without connection to God and ethics, then we end in insanity, like Nietzsche, to allege Bellinger's example (TS, loc. 2668-70). If we want to create an "ethical" society by refusing God and by denying of the sacredness of every human life, we end in insanity of Stalinism. If we want to be with God or to follow God but - on the other side - we refuse our self and we hate our neighbours, our fellow people, we end in insanity of $9 / 11$ hijackers (TS, loc. 2670-73). A sin includes alienation from God, resistance to the growth in self, and hatred against the fellow humans (TS, loc. 2621-24). When we comprehend the nature of these unbreakable bonds between the dimensions of reality then we find out that the principle "the aim consecrates the mean" is a philosophical mistake which originates in human psychopathology. There is no aim that could override the ethical since the ethical is inseparably connected with the authentic self and God's work of continuous creation (TS, loc. 2673-75).

\section{PROPER LOVE INCLUDES SELF-AFFIRMATION AND SELF-LOVE, BUT NOT SELF-APPROPRIATION}

The issue of Kierkegard's view on the relation between universal non-preferential neighbourly love and preferential loves (one's love of her children, country, church...) is very complex. However, one thing is sure: also according to Kierkegaard, the essence of love - in the sense of agape is service. But the question is who we ultimately serve? Within Christian horizon, this is quite clear: God. But serving God already implies that we do 
not only renounce, disavow, deny, forsake, but also develop, establish and nurture preferential loves, which are by nature unequal and exclusive, etc. All these exclusive, preferential, self-affirming, etc. things are needed if we want to become (special, unique) beings that God wants us to become. The supreme criterion of proper love is not self-denial and equality to all, but love for God, which consists of a consistent and unconditional observing of his will and therefore his desire about what we should be like and who we should become. This is in line with Kierkegaard's attitude, which permeates his entire oeuvre including Works of Love, that faith is the foundation of all good, and that without faith proper love is not possible. At the same time, such a view on the question of proper love frees us of the unnecessary and sometimes outright harmful bad conscience due to the preferential, unequal and self-affirmative sides of our life. In a certain sense, however, Christian truth is the exact opposite, which turns out to be the case when we consider Kirkegaard's works: not only the nurturing but also the neglecting of preferential inequalities and self-affirmative aspects of our life can be wrong, can be a sin, that is: something that is opposed to God's will. This reminds me of an anecdote from the life of the great Italian tenor Beniamino Gigli, who once asked a collocutor if he thought it right that he practices, sings and studies all day long while many people toil and still hardly make ends meet. He received the following answer: "Do you have so little appreciation for God, who gave you your immense singing talent?" Here, too, one needs to be humble, "down-to-earth" and respectful of God's will. Furthermore, this is in accord with the personalistic view and the attitude of virtue ethics, which foregrounds persons and their flourishing, and not a principle or a rule: the essential question is what kind of a person we have to be or become and not which principle is correct. However, on account of the idea of equality and self-denial, we must by no means destroy the development of individuals into different single individuals. What God wants is first and foremost that we become what he has intended us to become. Self-denial and neighbourly love is not the goal, but the means of becoming what God wants. Becoming a means is inappropriate both from the viewpoint of God's will and the realistic view of life. God has given us a determinate and unique image and our main and actually our only task is to realise it. In order for us to be aware of this, live accordingly and advance in getting to know the image assigned to us, we need faith. Life originating in other beliefs and values is not in accordance with 
God's will. This is why the following, which is something that Kierkegaard also pointed out in Works of Love, holds true: "Everything that does not come from faith is sin." (Romans 14:23) We come to the same point - that the supreme criterion is adhering to God's will - in trying to understand violence. Following Kierkegaard, Charles Bellinger (Bellinger 1992; 2001; 2008; 2010; Žalec 2014) found that violence starts with the resistance to the possibility of spiritual growth, which is to say the avoidance or even opposition to God's will and the avoidance of contact with God. Violence originates in the alienation from God.

According to Kierkegaard, we must not love our neighbour either more or less than ourselves (Ferreira 2013, 340). We must not do anything that would distance us from becoming the image God intended for us. Such action, even if it is "love," is irresponsible. Ferreira says that Works of Love distinguish

love that is a feeling of attraction or inclination from love that is best construed as a kind of responsibility for compassionate caring. Such responsibility is at the same time a debt to others that should be offered to them as a gift directed to their welfare. (Ferreira 2013, 341)

Also in accordance with this is the Christian doctrine that martyrdom cannot or must not be forced (Pieper 2008, 145ff). If God has not intended the "image" of a martyr for us, then it is not right if we try to go down this path. We could say that no matter how much we "love" the other, we must never become merely a means for their wellbeing. That is wrong. On the other hand, the other must never become merely a means for us, no matter how much we "love" or "need" them. In other words, in every relation and therefore in every love, we must take care that we respect the other's dignity. This is in accordance with Kierkegaard's emphasis on the significance of how, in what way we give or show love for the other: "Kierkegaard reveals an incredible sensitivity to the ways in which we express our compassionate caring, claiming that the way to love is to give the gift as if it were the recipient's own property (Ferreira 2013, 341)." We must therefore also forgive in a way that does not humiliate the other, warns Kierkegaard (Ferreira 2013, 340). In line with the above, Ferreira writes:

The point of Works of Love is to shock us into realising two things. First [...] that even when we have no inclination or attraction at all to someone, and even if they 
hate us, or resist or reject our love, we must preserve the love that respects the dignity and equality of each individual. Second [...] even in erotic love and friendship we must preserve the love that respects the dignity and equality of each individual. (Ferreira 2013, 341)

To love someone, according to Kierkegaard, means to endeavour for their wellbeing and contribute to it. But what is one's wellbeing? Kierkegaard says two things about this: 1 . To love God as much as possible; 2. To become one's own, oneself, free, independent, one's own master, to stand alone (Kierkegaard 1995, 274). "Insofar as the loving one is able, he seeks to encourage a person to become himself, to become his own master." (Kierkegaard 1995, 278) Someone can be themselves, their own master, etc., only insofar as they love God and vice versa: only insofar as they are themselves, they actually realise the love for God. This is also in accord with the essential moment of Kierkegaard's view on love, his belief that all love originates in God (Kondrla, Pavlíková 2016, 110). It is impossible to follow God's will if we are not in contact with God, and this following is precisely love. We can conclude that, according to Kierkegaard, love is always directed to what people have to be or become (Pavlíková 2016, 114). The one who loves gives the loved one what helps the latter to become the image God intended for them, to become God's image. This image that God intended for us is a gift, a gift of infinite divine love. In this context, it is not surprising that Kierkegaard thought that every love, regardless of its form, is possible only because we are infinitely loved (Pavlíková 2017; Králik and Jakobsen Tinley 2017). As he wrote in his diaries: "It is like a child's giving his parents a present, purchased however, with what the child has received from his parents." (Ferreira 2013, 342)

Ethics is a way of seeing. To be ethical means to see the other as I actually see them in their concreteness (Ferreira 2001, 106). According to Kierkegaard, we can preserve this concreteness in various ways. But we must by all means strive towards two things (Lippitt 2012, 193): firstly, not to become victims of our own fantasies. We must love the person as we actually see them, and not the image of them that we have ourselves produced (Kierkegaard 1995, 164). Secondly, to love a person as we see them does not mean we are blind to their faults. Love can be a challenge, but it can only be a challenge if we love the person as we see them. In this context, Ferreira points out Jesus's relation to Peter (just before he denied Jesus), which 
Kierkegaard noticed. Jesus does not think: Peter first has to change and then I will love him (again). No. His attitude is this: Peter is Peter, and my love, if anything, will help him to become a better person (Kierkegaard 1995, 172). For Christians, then, (their) love is not (merely) a matter of attraction (erotic or romantic love) nor merely an award for the ethicalness of the beloved, but first and foremost service: I love the other in order to help them become another or a better person. Christians believe that if there is anything that can help others and ourselves become better or other people, it is our love. This viewpoint can also be related to Jesus's commandment to love our enemies. What credit do we have if we love only those who attract us, who do us good, who are our friends or are (already) moral, good. According to Christianity, this is not just, for love belongs to all, everyone deserves love. Love belongs to everyone gratuitously. Since love is not a matter of justness, respect, merit, pleasure, etc., but serving with the intention of bettering the loved person, which is why it (can) also be a commandment since it makes sense in the Christian horizon for us to strive for others to become other or better persons. But if this is not commanded - that we have to strive for others to become better persons - or if it is not believed that this can be achieved with love, then love as a commandment is also nonsensical. Furthermore, as Ferreira points out: if God's love has to be a model for proper human love, then this implies that both have to focus on "concrete differences" (Ferreira 2001, 112; Lippitt 2012, 194). She refers us to the following passage in Works of Love:

With what infinite love nature or God in nature encompasses all the diverse things that have life and existence! Just recollect what you yourself have so often delighted in looking at, recollect the beauty of the meadows! There is no difference in the love, no, none - yet what a difference in the flowers! Even the least [...] flower disregarded by even its immediate surroundings, the flower you can hardly find without looking carefully - it is as if this, too, had said to love: Let me become something in myself, something distinctive. And then love has helped it to become its own distinctiveness, but far more beautiful than the poor little flower had ever dared to hope for. What love! First, it makes no distinction, none at all; next [...] it infinitely distinguishes itself in loving the diverse. Wondrous love! For what is as difficult as to make no distinction at all in loving, and if one makes no distinction at all, what is as difficult as making distinctions! (Kierkegaard 1995, 269-70)

As Pia Søltoft, following Kierkegaard, pointed out, to love is to be one with oneself (Králik, Torok 2016, 70). Our highest possible achievement 
is that we develop our single individuality, our authentic uniqueness. This is the most what one can "get." But at the same time this is the most what one can give or offer. As Milbank has pointed out - when explaining the view which Valčo called "agape personalism" (Valčo 2016) - love is always "personal" and "singular" also regarding the giving, not just receiving: "the highest thing which all can offer is now nothing general to which they should aspire; it is instead simply their given real selves, their own uniqueness, which is inseparable from their unique set of relations to others.' (Valčo 2016, 98)

Let us conclude with the warning that we should not confuse self-love in a positive sense with self-love in a negative sense. Let's call the last self-appropriation. Kierkegaard believed that we must be absolutely humble before God and give him priority over everything else. God must be our absolute priority (Kierkegaard 1995, 149, 448). This is the only way we can protect ourselves from self-appropriation. Self-appropriation is the most important thing we must overcome in life (Kierkegaard 1995, 17). I think it is quite reasonable to say that one of the main purposes of Kierkegaard's writing is to show human beings how they can protect themselves from self-appropriation and overcome it. Because Kierkegaard's ethics is primarily an ethics of love (Evans 2008), we can formulate the above statements as the demand for the primacy of the love of God. The significance of the primacy of the love of God can be illuminated from the aspect of idolatry. The primacy of the love of God is significant because any attitude that favours anything over God is idolatry. In order to understand this better, we must take into account the central significance of creation in Kierkegaard's thought. Human beings without faith, which according to Kierkegaard is equivalent to the priority of the love of God, thereby avoid God's creation of them and thus become or try to become or be their own "creator." This amounts to the idolatry of oneself since one tries to assume God's function. It is needless to add that, according to the Christian doctrine, such self-idolatry is self-appropriation, regardless of what one does.

\section{ACKNOWLEDGMENT}

This paper is a result of the The Research Programme Ethical-religious Grounds and Perspectives of the Society and the Religious Studies in Context 
of Education and Violence (P6-0269) and basic research projects The Return of the Religious in Postmodern Thought as a Challenge for Theology (J6-7325), Reanimating Cosmic Justice: Poetics of the Feminine (J6-8265) and Interreligious Dialogue - a Basis for Coexisting Diversity in the Light of Migration and the Refugee Crisis (J6-9393), which are financed by the Slovenian Research Agency.

\section{REFERENCES}

Bellinger Ch. K. (1992), Toward a Kierkegaardian Understanding of Hitler, Stalin, and the Cold War, in: Foundations of Kierkegaard's Vision of Community: Religion, Ethics, and Politics in Kierkegaard, eds. G. B. Connell, C. S. Evans, New Jersey, pp. 218-230.

Bellinger Ch. K. (2001), The Genealogy of Violence: Reflections on Creation, Freedom, and Evil, New York.

Bellinger Ch. K. (2008), The Trinitarian Self: The Key to the Puzzle of Violence, Oregon.

Bellinger Ch. K. (2010), The Joker Is Satan, and So Are We: And Other Essays on Violence and Christian Faith, Fort Worth.

Bellinger Ch. K. (2015), The Trinitarian Self: The Key to the Puzzle of Violence, Edition Kindle.

Evans C. S. (2008), Kierkegaard's Ethic of Love: Divine Commands \& Moral Obligations, Oxford.

Fererira M. J. (2001), Love's Grateful Strivings: A Commentary on Kierkegaard's Works of Love, Oxford.

Fererira M. J. (2013), Love, in: The Oxford Handbook of Kierkegaard, eds. J. Lippitt, G. Pattison, Oxford, pp. 328-343.

Kierkegaard S. (1991), Practice in Christianity, trans. H. V. Hong, Princeton.

Kierkegaard S. (1995), Works of Love, trans. H. V. Hong, E. H. Hong, Princeton.

Kondrla P., Pavlíková M. (2016), From Formal Ethics to Existential Ethics, "European Journal of Science and Theology" 12 (3), pp. 101-111.

Králik R., Torok L. (2016), Concept of Relationship God-Man in Kierkegaard's Writing 'What We Learn From the Lilies in the Field and From the Birds in the Air', "European Journal of Science and Theology" 12 (2), pp. 65-74.

Králik R., Jakobsen Tinley S. (2017), Kierkegaard's Ethics as an Answer to Human Alienation in Technocratic Society, "Komunikácie" 19 (1), pp. 25-29.

Lippitt J. (2012), Kierkegaard and the Problem of Special Relationships: Ferreira, Krishek, and 'God Filter', "International Journal for Philosophy of Religion" 72 (3), pp. 177-197.

Pavlíková M. (2016), The Concept of Anxiety and Its Reflection in Auden's Work 'The Age of Anxiety', "European Journal of Science and Theology" 12 (4), pp. 111-119.

Pavlíková M. (2017), Reading Auden as a Resource for Existential Reflection in a Society with Technocratic and Hedonistic Tendencies, "Komunikácie" 19 (1), pp. 39-43. 
Pieper J. (2008), Über die Tugenden, $2^{\text {nd }}$ ed., München.

Valčo M. (2016), Kierkegaard's 'Sickness Unto Death' as a Resource in Our Search for Personal Authenticity, "European Journal of Science and Theology" 12 (1), pp. 97-105. Žalec B. (2014), Nazism and Stalinism in the Light of Kierkegaard's Thought, "Filozofia" 69 (5), pp. 443-450. 